\title{
Diffuse nodular lymphoid hyperplasia of the colon
}

\section{Guzkowy przerost limfoidalny w jelicie grubym}

\author{
Anastasios Koulaouzidis ${ }^{1}$, Mariusz Madalinski \\ ${ }^{1}$ Centre for Liver \& Digestive Disorders, The Royal Infirmary of Edinburgh, UK \\ ${ }^{2}$ Gastroenterology Department, NHS Lothian, University Hospitals Division, Western General Hospital, Edinburgh, UK
}

Przegląd Gastroenterologiczny 2012; 7 (2): 108-110

DOI: $10.5114 /$ pg.2012.28653

Słowa kluczowe: guzkowy przerost limfoidalny, polipy, kolonoskopia, chromoendoskopia. Key words: nodular lymphoid hyperplasia, polyps, colonoscopy, chromoendoscopy.

\begin{abstract}
Address for correspondence: Dr Anastasios Koulaouzidis MD, MRCP, FEBG, Centre for Liver and Digestive Disorders (CLDD), Royal Infirmary of Edinburgh, 51 Little France Crescent, Old Dalkeith Road, Edinburgh, UK, EH164SA, phone: +44 1312421126 ,
\end{abstract} sec: +44 131 2421619, mobile: +44 7783355 456, e-mail: Tassos.Koulaouzidis@luht.scot.nhs.uk

\begin{abstract}
Diffuse nodular lymphoid hyperplasia (DNLH) of the alimentary tract is regarded as a very uncommon finding in the adult population. It is characterized by the presence of numerous visible tiny polypoid masses uniformly distributed through the involved segment, representing an exaggeration of the normal gut-associated lymphoid follicle pattern. The DNLH usually occurs in the small bowel. We report an unusual case of DNLH of the colon in an adult woman who presented with constipation. The DNLH mimics a variety of polyposis syndromes and this may cause difficulties in diagnosis.
\end{abstract}

\section{Introduction}

Diffuse nodular lymphoid hyperplasia (DNLH) is characterized by sizeable lymphoid nodules. When found in the colon, these nodules may cause difficulties in diagnosis, as they mimic a variety of polyposis syndromes and associated pathologies.

\section{Case report}

A 48-year-old woman presented to her general practitioner with 6 weeks' history of constipation, but no other associated systemic symptoms. She also reported increased frequency of upper respiratory tract infections and headaches.

The patient underwent colonoscopy and as a bowel preparation she received 2 sachets of sodium picosulphate and magnesium oxide. Insertion of the colonoscope to the terminal ileum was straightforward and

\section{Streszczenie}

Rozlany guzkowy przerost limfoidalny (diffuse nodular lymphoid hyperplasia - DNLH) jest rzadką zmianą przewodu pokarmowego $u$ dorosłych. Charakteryzuje się występowaniem licznych drobnych polipów równomiernie rozproszonych w zajętym segmencie jelita, będących pobudzonymi, powiększonymi grudkami chtonnymi. Zwykle jest on rozpoznawany $w$ jelicie cienkim. W pracy przedstawiono rzadko diagnozowany DNLH w jelicie grubym (obejmujący jelito od wstępnicy do zstępnicy) u kobiety cierpiącej z powodu zaparcia stolca. Może on imitować zespoły polipowatości jelita grubego i dlatego sprawia trudności diagnostyczne.

uneventful. White light colonoscopy revealed irregular mucosa with numerous, subtle nodular lesions from the descending to the ascending colon. This pattern became more prominent under vital staining with $0.8 \%$ indigo carmine dye spray (Figure 1). Multiple biopsies were obtained from both the right and the left colon. Histological examination showed prominent lymphoid aggregates in the lamina propria, with no evidence of mucosal inflammation or malignancy, and no evidence of increased sub-epithelial collagen table thickness.

The patient was subsequently reviewed in the clinic. Since her colonoscopy, she had no more problems with her bowels. Physical examination was overall unremarkable. She had an extensive set of laboratory investigations, including full blood count, total protein, serum immunoglobulin electrophoresis, vitamins, coeliac serology, inflammation indices and faecal calprotectin as well as stool microscopy. They were all normal. 


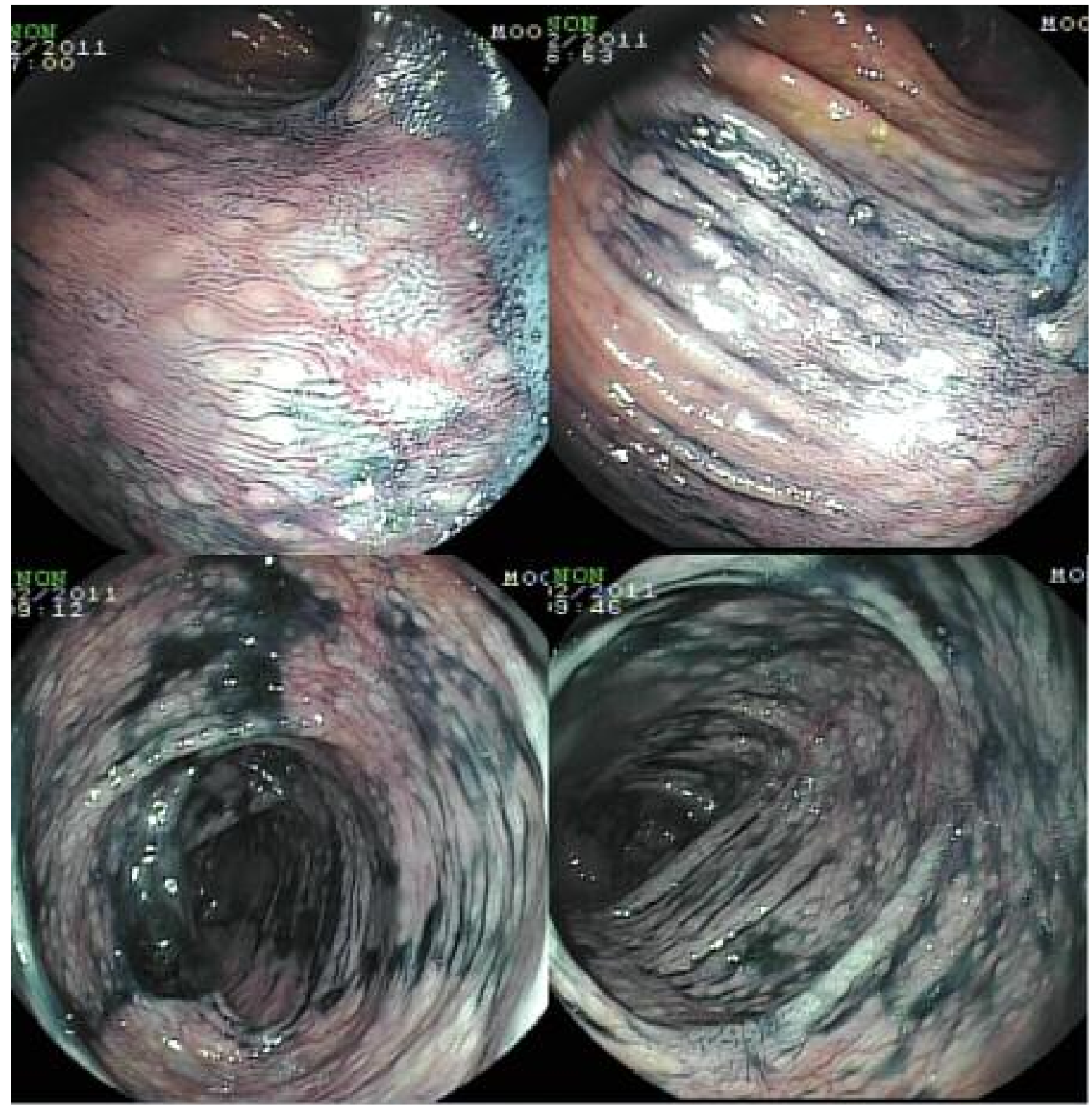

Fig. 1. Colonoscopic picture of polyps (3-5 mm in diameter) after applying indocarmine spray (diluted, 0.8\%) in 48-year-old woman with diffuse nodular lymphoid hyperplasia. Chromoendoscopy makes targeting biopsies easier and was utilised to delineate mucosal surface details

Ryc. 1. Obraz kolonoskopowy polipów (o rozmiarach 3-5 mm) po zastosowaniu sprayu z 0,8\% karminu indygo u 48-letniej pacjentki z rozlanym guzkowym przerostem limfoidalnym. Chromoendoskopia ułatwia przeprowadzenie precyzyjnych biopsji i została zastosowana w celu lepszego uwidocznienia zarysów śluzówki

\section{Discussion}

Diffuse nodular lymphoid hyperplasia (DNLH) is regarded as a very uncommon finding in the adult population; it has been mostly described in children, representing an exaggeration of the normal gut-associated lymphoid follicle pattern [1, 2]. Endoscopically, polypoid nodules up to $5 \mathrm{~mm}$ in size are seen [3]. Sizeable lymphoid nodules in the colon can be easily confused with other pathologies due to their number. Although DNLH is generally asymptomatic, it always requires differential diagnosis from colonic polyposis syndromes and malignant lymphoma [4]. 
DNLH has been reported in association with inflammatory bowel disease, variable immunodeficiency, bacterial overgrowth, recurrent giardiasis and rarely malignant, intestinal lymphoma $[4,5]$. Helicobacter pylori is also probably linked with duodenal DNLH [6]. Although, the aetiology of DNLH in adults is unknown, in children it may be related to food hypersensitivity and/or viral infections [6-8]. Moreover, it has been suggested that DNLH in adults may be a risk factor for intestinal and extra-intestinal lymphoma $[4,6,8,9]$.

In our case, as there was no background of immunodeficiency, DNLH was considered benign and reassurance was offered. The appropriate interval for endoscopic surveillance, should one is necessary, has yet to be defined. During subsequent colonoscopies, biopsies should be obtained from enlarging nodules to exclude germinal transformation.

\section{References}

1. Colarian J, Calzada R, Jaszewski R. Nodular lymphoid hyperplasia of the colon in adults: is it common? Gastrointest Endosc 1990; 36: 421-2.

2. Schwartz DC, Cole CE, Sun Y, et al. Diffuse nodular lymphoid hyperplasia of the colon: polyposis syndrome or normal variant? Gastrointest Endosc 2003; 58: 630-2.

3. Bharadhwaj G, Triadafilopoulos G. Endoscopic appearances of colonic lymphoid nodules: new faces of an old histopathological entity. Am J Gastroenterol 1995; 90: 946-50.

4. Piascik M, Rydzewska G, Pawlik M, et al. Diffuse nodular lymphoid hyperplasia of the gastrointestinal tract in patient with selective immunoglobulin A deficiency and sarcoid-like syndrome - case report. Adv Med Sci 2007; 52: 296-300.

5. Tomita S, Kojima M, Imura J, et al. Diffuse nodular lymphoid hyperplasia of the large bowel without hypogammaglobulinemia or malabsorption syndrome: a case report and literature review. Int J Surg Pathol 2002; 10: 297-302.

6. Khuroo MS, Khuroo NS, Khuroo MS. Diffuse duodenal nodular lymphoid hyperplasia: a large cohort of patients etiologically related to Helicobacter pylori infection. BMC Gastroenterol 2011; 11: 36.

7. Iacono G, Ravelli A, Di Prima L, et al. Colonic lymphoid nodular hyperplasia in children, relationship to food hypersensitivity. Clin Gastroenterol Hepatol 2007; 5: 361-6.

8. Pytrus T, Iwańczak B, Iwańczak F. Nodular lymphoid hyperplasia: underestimated problem of gastrointestinal tract pathology in children. Pol Merkur Lek 2008; 24: 449-52.

9. Postgate A, Despott E, Talbot I, et al. An unusual cause of diarrhea: diffuse intestinal nodular lymphoid hyperplasia in association with selective immunoglobulin A deficiency (with video). Gastrointest Endosc 2009; 70: 168-9. 